\title{
PENGARUH MODEL PEMBELAJARAN BERDASARKAN MASALAH TERHADAP HASIL BELAJAR SISWA PADA MATERI POKOK SUHU DAN KALOR
}

\author{
Purwanto*) dan Yuli Purnama**) \\ *) Dosen Fisika Unimed \\ **) Mahasiswa Fisika Unimed \\ Email : purwantofisika@gmail.com
}

\begin{abstract}
ABSTRAK
Penelitian ini bertujuan untuk mengetahui pengaruh model pembelajaran berdasarkan masalah terhadap hasil belajar siswa kelas X SMA Negeri 1 Langsa T.P 2014/2015. Jenis penelitian ini adalah quasi eksperimen dan desain yang digunakan adalah control group pretest and posttest. Populasi penelitian ini adalah seluruh siswa kelas X SMA Negeri 1 Langsa yang terdiri dari 8 kelas dan sampel penelitian diambil 2 kelas dengan teknik cluster random sampling, yaitu kelas X MIA 1 menggunakan model pembelajaran berdasarkan masalah dan kelas $\mathrm{X}$ MIA 3 menggunakan model pembelajaran konvensional. Hasil penelitian, diperoleh postes dengan rata-rata kelas eksperimen 81,08 dan kelas kontrol 77,13. Hasil pengujian hipotesis yaitu $\mathrm{H}_{\mathrm{a}}$ diterima, dengan kata lain ada perbedaan akibat pengaruh model pembelajaran berdasarkan masalah terhadap hasil belajar siswa pada materi pokok Suhu dan Kalor kelas X SMA Negeri 1 Langsa T.P 2014/2015.
\end{abstract}

Kata kunci : model pembelajaran berdasarkan masalah, hasil belajar, suhu dan kalor

\section{EFFECTS OF PROBLEM BASED LEARNING MODEL OF STUDENT LEARNING OUTCOMES IN THEMPERATUR AND HEAT CONTENT}

\begin{abstract}
Abstract. The objective of this study to determine effects of Problem Based Learning Model of student learning outcomes in Themperatur and Heat content of class X Semester II SMA Negeri 1 Langsa. The study was quasi experimental and control group pretest and posttest design. The entire population of students of class X SMA Negeri 1 Langsa consisting of 8 classes with samples were taken 2 classes with cluster random sampling technique, the class X MIA 1 using problem based learning model and class X MIA 3 using conventional learning model. The result obtained by the average value of the experimental class postest were 81,08 and 77,13 control class. Hypothesis testing results obtained is $H_{a}$ is accepted, in other words there is difference due to the effect of problem based learning model of student learning outcomes in Themperatur and Heat content of class X SMA Negeri 1 Langsa T.P 2014/2015.
\end{abstract}

Keywords : problem based learning model, student learning outcomes, themperatur and heat 


\section{PENDAHULUAN}

Peradaban manusia akan sangat diwarnai oleh tingkat penguasaan ilmu pengetahuan dan teknologi. Pengembangan ilmu pengetahuan dan teknologi akan bersumber pada Sains yakni Matematika dan Ilmu Pengetahuan Alam (IPA). Fisika sebagai salah satu unsur dalam IPA mempunyai peranan yang sangat penting dan strategis dalam pengembangan teknologi masa depan. Oleh karena itu dalam memacu ilmu pengetahuan dan teknologi, proses pembelajaran fisika perlu mendapat perhatian yang lebih baik mulai dari tingkat pendidikan SD sampai perguruan tinggi. Terkait dengan upaya peningkatan mutu pendidikan, berbagai hal telah dilakukan pemerintah, antara lain: penyempurnaan kurikulum, pengadaan buku ajar, peningkatan mutu guru dan tenaga kependidikan melalui berbagai pelatihan dan peningkatan kualitas pendidikan. Meskipun upaya-upaya yang disebutkan di atas telah dilakukan, namun hasilnya belum seperti yang diharapkan.

Mutu pendidikan sains (khususnya fisika) di berbagai jenjang pendidikan di Indonesia masih rendah. Hal ini sejalan dengan data The Learning Curve Pearson tahun 2014 menunjukkan bahwa Indonesia menempati posisi ke-40 dengan indeks rangking dan nilai secara keseluruhan yakni -1,84, sementara pada kategori kemampuan kognitif indeks rangking Indonesia dengan nilai 2,11. Ini menunjukkan tidak adanya perbaikkan signifikan yang dibuat Indonesia dalam perbaikan sumber daya manusianya (tribunnews.com, 10 Maret 2015).
Rendahnya kualitas pendidikan yang dihasilkan tidak terlepas dari berbagai faktor di antaranya pengemasan pembelajaran, proses pembelajaran fisika yang berlangsung masih berorientasi pada buku teks dan ketercapaian kurikulum dengan didominasi oleh pembelajaran langsung. Pada proses pembelajaran suasana kelas cenderung teachercentered sehingga siswa cenderung pasif dalam mengikuti pembelajaran, kurang memiliki inisiatif di kelas, dan kurang kreatif dalam berpikir.

Daftar Kumpulan Nilai (DKN) hasil observasi siswa kelas $\mathrm{X}$ tahun ajaran 2013-2014 SMA Negeri 1 Langsa menunjukkan bahwa nilai rata-rata ulangan harian pelajaran Fisika pada materi Suhu dan Kalor yang diperoleh adalah 62. Nilai tersebut masih dikatakan rendah dan belum mencapai Kriteria Ketuntasan Minimal (KKM) yakni 75. Dari angket yang disebar kepada 35 orang siswa menunjukkan bahwa $86 \%$ siswa tidak menyukai pelajaran fisika dan menganggap fisika adalah mata pelajaran yang sulit, hanya $11 \%$ siswa mengatakan bahwa proses pembelajaran di kelas berlangsung dengan melakukan eksperimen dan $15 \%$ siswa yang mengatakan proses pembelajaran berlangsung dengan melakukan diskusi dan tanya jawab, hal tersebut diperkuat dengan hasil wawancara dengan salah seorang guru fisika di SMA Negeri 1 Langsa, bahwa dalam proses pembelajaran jarang dilaksanakan eksperimen dikarenakan tidak semua materi pembelajaran fisika yang dapat dilaksanakan secara eksperimen serta terbatasnya alat. Beliau juga mengatakan bahwa keaktifan siswa dalam proses pembelajaran masih rendah dan kurangnya minat siswa akibat tidak terlibat langsung dalam 
masalah. Bila hal tersebut tidak ditangani dengan serius, masalah tersebut akan terus-menerus menghambat proses pembelajaran dan berimbas kepada hasil belajar yang rendah.

Perlu ditemukan cara yang terbaik untuk menyampaikan berbagai konsep yang diajarkan sehingga siswa dapat menggunakan dan mengingat lebih lama konsep tersebut. Maka guru pun dituntut dapat berkomunikasi baik dengan siswanya, dapat membuka wawasan berpikir yang beragam dari seluruh siswa, sehingga dapat mempelajari berbagai konsep dan cara mengaitkannya dalam kehidupan nyata serta dapat memilih model pembelajaran yang dapat memacu semangat setiap siswa untuk secara aktif ikut terlibat dalam pengalaman belajarnya.

Berdasarkan pertimbangan tersebut dan masalah-masalah yang dihadapi siswa SMA Negeri 1 Langsa, maka salah satu alternatif model pembelajaran yang memungkinkan dikembangkannya keterampilan berpikir siswa dalam memecahkan masalah dan keterlibatan siswa dalam pengalaman belajarnya adalah pembelajaran berbasis masalah (PBM).

Arends (2013) mengatakan "Pengajaran berdasarkan masalah merupakan suatu pendekatan pembelajaran dimana siswa mengerjakan permasalahan yang autentik dengan maksud untuk menyusun pengetahuan mereka sendiri, mengembangkan inkuiri dan keterampilan berpikir tingkat lebih tinggi, mengembangkan kemandirian dan percaya diri". Model pembelajaran berdasarkan masalah (problem based learning) merupakan suatu model pembelajaran yang didasarkan pada banyaknya permasalahan yang membutuhkan penyelidikan autentik yakni penyelidikan yang membutuhkan penyelesaian nyata dari permasalahan yang nyata (Trianto: 2012 ; Rusman: 2012). Sanjaya (2009) juga berpendapat bahwa PBL dapat diartikan sebagai rangkaian aktivitas pembelajaran yang menekankan pada proses penyelesaian masalah yang dihadapi secara ilmiah.

Model

pembelajaran

berdasarkan masalah mampu mengajak siswa kedalam suatu pembelajaran penyelidikan masalahmasalah dan melibatkannya langsung dalam penyelesaian masalah tersebut, pembelajarannya yang realistik dengan kehidupan siswa, dapat membuat ketahanan ingatan siwa terhadap konsep lebih lama, mengeksplor kemampuan memecahkan masalah serta konsep yang dibelajarkan sesuai dengan kebutuhan dan dekat dengan kehidupan siswa.

Pelaksanaan pembelajaran dengan model pembelajaran berdasarkan masalah, diharapkan siswa dapat terlibat langsung dalam penyelidikan masalah yang dapat berupa eksperimen maupun diskusi sehingga timbulnya minat dalam belajar fisika serta meningkatkan kemampuan berpikir dan memecahkan masalah yang berujung pada peningkatan hasil belajar.

Tujuan penelitian yang dilakukan adalah untuk mengetahui adanya perbedaan akibat pengaruh model pembelajaran berdasarkan masalah terhadap hasil belajar siswa pada materi pokok Suhu dan Kalor Kelas X Semester II SMA Negeri 1 Langsa T.P.2014/2015. 


\section{METODE PENELITIAN}

Penelitian ini merupakan penelitian eksperimen dengan desain pretest-posttest control group design. Desain penelitian ini ditunjukkan pada Tabel 1.

Tabel 1. Two Group Pretest-Postest

\begin{tabular}{|l|c|c|c|}
\hline $\begin{array}{l}\text { Kelompok/ } \\
\text { Kelas }\end{array}$ & Pretes & Perlakuan & Postes \\
\hline $\begin{array}{l}\text { Kelas } \\
\text { eksperimen }\end{array}$ & $\mathrm{T}_{1}$ & $\mathrm{X}$ & $\mathrm{T}_{2}$ \\
$\begin{array}{l}\text { Kelas } \\
\text { kontrol }\end{array}$ & $\mathrm{T}_{1}$ & $\mathrm{Y}$ & $\mathrm{T}_{2}$ \\
\hline
\end{tabular}

Keterangan :

$\mathrm{T}_{1}=$ Pretes diberikan kepada kelas eksperimen dan kelas kontrol sebelum perlakuan

$\mathrm{T}_{2}=$ Postes diberikan setelah perlakuan pada kelas eksperimen dan kelas kontrol

$\mathrm{X}=$ Pengajaran dengan menerapkan model pembelajaran berbasis masalah

$\mathrm{Y}=$ Pengajaran dengan menerapkan model pembelajaran konvensional

$\mathrm{T}_{1}=\mathrm{T}_{2}$

Populasi dalam penelitian ini adalah seluruh siswa kelas $\mathrm{X}$ semester II SMA Negeri 1 Langsa tahun ajaran 2014/2015. Sampel yang digunakan adalah kelas X MIA 1 sebagai kelas eksperimen dan kelas X MIA 3 sebagai kelas kontrol.

Variabel bebas dalam penelitian ini adalah model pembelajaran berdasarkan masalah dan model pembelajaran konvensional sedangkan variabel terikatnya adalah hasil belajar pada materi pokok Suhu dan Kalor siswa SMA Negeri 1 Langsa kelas X semester II tahun ajaran 2014/2015.
Sebelum diberikan perlakuan, kedua kelas diberi pretes. Pembelajaran dilakukan dengan menerapkan model berdasarkan masalah untuk kelas eksperimen dan model pembelajaran konvensional untuk kelas kontrol.

Tes yang akan diberikan kepada sampel terlebih dahulu divalidkan kepada tiga validator. Selanjutnya dari hasil validasi oleh validator, tes diuji cobakan kepada 28 siswa kelas XI untuk mengetahui validitas dan reliabilitas tes.

Hasil uji validasi dengan merumuskan korelasi product moment, dari 15 butir soal hanya 7 soal yang dinyatakan valid dan 8 soal butir soal yang dinyatakan tidak valid, dengan demikian peneliti hanya mengambil jumlah item soal yang dinyatakan valid. Selanjutnya, untuk menguji reliabilitas tes digunakan rumus Alpha Cronboach diperoleh $\mathrm{r}_{\text {hitung }}=0,52$ yaitu $0,40<\mathrm{r}_{\text {hitung }} \leq 0,60$ sehingga dapat disimpulkan bahwa tes yang digunakan memiliki reliabilitas sedang.

\section{HASIL DAN PEMBAHASAN Hasil}

Sebelum materi diajarkan, terlebih dahulu siswa diberi pretes untuk mengetahui kemampuan awal siswa terhadap materi yang diteliti pada kelas eksperimen dan kelas kontrol.

Adapun hasilnya menunjukkan bahwa nilai rata-rata pretes yang diperoleh dikelas eksperimen adalah 50,16. Diagram batang hasil pretes kelas eksperimen ditunjukkan pada Gambar 1. 


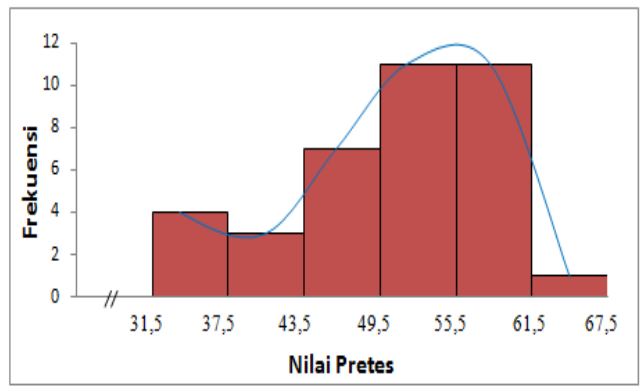

Gambar 1. Grafik Data Pretes Kelas Eksperimen

Grafik 1. menggambarkan bahwa kurva frekuensi berupa model negatif, hal tersebut terjadi karena soal tes yang terlalu mudah sehingga banyak peserta yang mendapat nilai baik.

Nilai rata-rata pretes yang diperoleh dikelas kontrol adalah 51,70. Diagram batang hasil pretes kelas kontrol ditunjukkan pada Gambar 2.

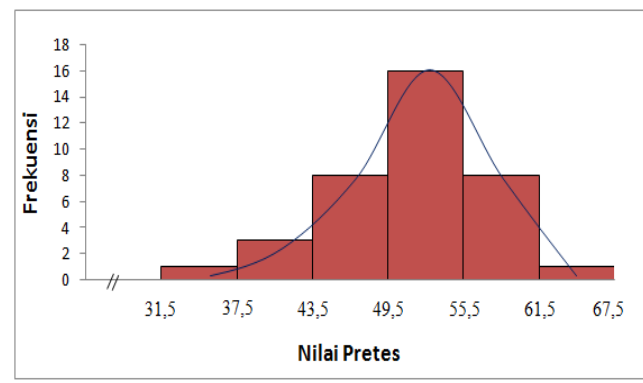

Gambar 2. Grafik Data Pretes Kelas Kontrol

Grafik 2. menggambarkan bahwa kurva frekuensi berupa model negatif, hal tersebut terjadi karena soal tes yang terlalu mudah sehingga banyak peserta yang mendapat nilai baik.

Setelah kedua kelas diberikan pretes, maka penelitian dilanjutkan dengan memberikan perlakuan yang berbeda. Pada kelas eksperimen diterapkan model pembelajaran berdasarkan masalah dilakukan oleh peneliti, sedangkan pada kelas kontrol diterapkan pembelajaran konvensional dilakukan oleh peneliti juga. Dikedua kelas kegiatan pembelajaran dilakukan sebanyak enam kali pertemuan.

Setelah diberi perlakuan, kedua kelas diberi postes nilai rata-rata postes yang diperoleh dikelas eksperimen adalah 81,08. Diagram batang hasil postes kelas eksperimen ditunjukkan pada Gambar 3.

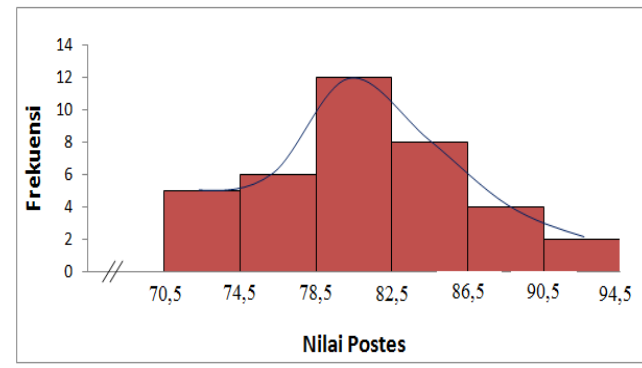

Gambar 3. Grafik Data Postes Kelas Eksperimen

Grafik 3. menggambarkan bahwa kurva frekuensi berupa model negatif, hal tersebut terjadi karena soal tes yang terlalu mudah sehingga banyak peserta yang mendapat nilai baik.

Nilai rata-rata postes yang diperoleh dikelas kontrol adalah 77,13. Diagram batang hasil postes kelas kontrol ditunjukkan pada Gambar 4.

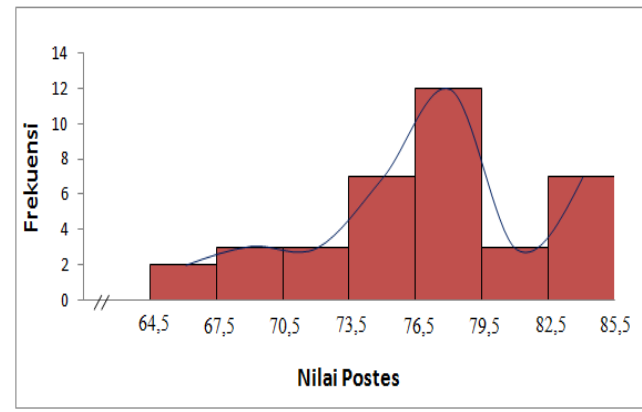

Gambar 4. Grafik Data Postes Kelas Kontrol

Grafik 4. menggambarkan bahwa kurva frekuensi berupa model negatif, hal tersebut terjadi karena soal tes yang terlalu mudah sehingga 
banyak peserta yang mendapat nilai baik.

Untuk menguji normalitas data digunakan uji Lilliefors yang bertujuan untuk mengetahui apakah penyebaran data hasil belajar siswa memiliki sebaran data yang berdistribusi normal atau tidak. Sampel berdistribusi normal jika dipenuhi $\mathrm{L}_{0}<\mathrm{L}_{\text {tabel }}$ pada taraf signifikan $\alpha=0,05$.

Berdasarkan hasil perhitungan uji normalitas, data tes pada kelas eksperimen untuk nilai pretes dan postes diperoleh hasil sebagai berikut: untuk data pretes diperoleh bahwa sebaran data pretes dikelas eksperimen berdistribusi normal. sedangkan data postes diperoleh bahwa sebaran data postes dikelas eksperimen berdistribusi normal. Sedangkan data tes pada kelas kontrol untuk nilai pretes dan postes diperoleh hasil sebagai berikut : untuk data pretes diperoleh bahwa sebaran data pretes dikelas kontrol berdistribusi normal. Untuk data postes diperoleh bahwa sebaran data postes dikelas kontrol berdistribusi normal.

Uji normalitas diperoleh bahwa sampel berasal dari distribusi normal, maka langkah selanjutnya adalah uji homogenitas. Pengujian homogenitas data untuk mengetahui apakah sampel yang digunakan dalam penelitian berasal dari populasi yang homogen atau tidak. Maksudnya apakah sampel yang dipilih dapat mewakili seluruh populasi yang ada. Uji homogenitas yag digunakan adalah uji $\mathrm{F}$ dengan $\alpha$ $=0,05$, dk pembilang $=36 \mathrm{dan} d \mathrm{k}$ penyebut $=36$. Kriteria pengujian homogenitas yang harus dipenuhi adalah $\mathrm{F}_{\text {hitung }}<\mathrm{F}_{\text {tabel }}$.

Berdasarkan hasil perhitungan uji homogenitas pada data pretest diperoleh bahwa pretes kedua sampel berasal dari varians yang homogen, pada data postes diperoleh bahwa postes kedua sampel berasal dari varians yang homogen.

Setelah diketahui bahwa untuk data tes hasil belajar kedua sampel berdistribusi normal dan homogen, selanjutnya dilakukan pengujian hipotesis. Dalam menguji kemampuan awal siswa digunakan uji t dua pihak, diperoleh bahwa antara kelas eksperimen dan kelas kontrol mempunyai kemampuan awal yang sama. Sedangkan untuk mengetahui pengaruh hasil belajar siswa kelas eksperimen dan kelas kontrol dilakukan uji t satu pihak, diperoleh bahwa antara kelas eksperimen dan kelas kontrol mempunyai kemampuan awal yang sama.

\section{Pembahasan}

Hasil penelitian menunjukkan bahwa hasil belajar siswa dengan menggunakan model pembelajaran berdasarkan masalah lebih baik dibandingkan dengan hasil belajar siswa dengan menggunakan model pembelajaran konvensional, hal ini dapat dilihat dari hasil postes kelas eksperimen memperoleh nilai ratarata 81,08 dengan jumlah siswa tuntas yaitu 32 siswa atau sebesar $86,48 \%$, sedangkan hasil postes kelas kontrol memperoleh nilai rata-rata postes 77,13 dengan jumlah siswa tuntas yaitu 27 siswa atau sebesar 71,97\%.

Peningkatan hasil belajar terjadi pada kelas eksperimen maupun kontrol, namun peningkatan terbesar terjadi pada kelas eksperimen. Ada beberapa hal yang menyebabkan penggunaan pembelajaran berbasis masalah dan metode tutor teman sebaya dapat meningkatkan hasil belajar siswa. Pertama, dengan diterapkannya pembelajaran berbasis masalah dan tutor teman sebaya ini, 
siwa selalu mendapatkan motivasi dari guru untuk selalu belajar dengan giat dan rajin karena dengan adanya motivasi, siswa akan belajar lebih keras, ulet, tekun dan memiliki konsentrasi penuh dalam proses belajar pembelajaran. Dorongan motivasi dalam belajar merupakan salah satu hal yang perlu dibangkitkan dalam upaya pembelajaran di sekolah (Dimayati dan Mudjiono : 2011).

Kedua, guru mengelompokan siswa untuk belajar. Belajar kelompok merupakan salah satu trik guru untuk memberikan kebebasan berpendapat kepada sesama siswa, hal yang dianggap sulit oleh siswa pada saat belajar sendirian maka didalam kelompok menjadi mudah oleh siswa karena anggota kelompok yang lain bisa membantu dan mencari jawabannya (Kunandar : 2010).

Ketiga, guru memberikan dorongan kepada siswa untuk mencari informasi tentang pelajaran fisika sebanyakbanyaknya sehingga mereka mempunyai pengetahuan yang banyak terhadapa materi tersebut (Kunandar : 2010).

Keempat, guru membantu siswa dalam merencanakan dan menyiapkan karya dan membantu mereka untuk berbagai tugas supaya mereka aktif dalamm membuat tugas sepaerti laporan (Dimayati dan Mudjiono : 2011).

Model

pembelajaran

berdasarkan masalah lebih baik daripada pembelajaran konvensional, karena memberikan peluang kepada siswa secara aktif terlibat dalam kegiatan pembelajarannya, hal ini terlihat melalui fase demi fase dalam model ini khususnya fase ketiga, dimana siswa melakukan investigasi atau penyelidikan secara berlelompok dengan melakukan studi literatur dan bereksperimen untuk membantu memecahkan masalah terkait materi pokok Suhu dan Kalor. Melalui eksperimen siswa dituntut untuk dapat memberdayakan kemampuan berpikir sesuai pengetahuan yang dimiliki, dalam hal ini mengemukakan hipotesis dan menganalisis hasil studi literatur serta menarik kesimpulan sehingga apa yang diperoleh siswa tidak hanya mengingat fakta-fakta melainkan menemukan langsung fakta.

Keterlibatan siswa secara aktif dalam kegiatan pembelajaran berdasarkan masalah juga terlihat melalui fase keempat, dimana siswa secara berkelompok ditugaskan untuk mengembangkan hasil studi literatur dan hasil eksperimen dalam bentuk laporan diskusi, dengan diskusi siswa akan berusaha untuk menemukan dan mempelajari konsep-konsep materi pelajaran serta berusaha untuk memunculkan ide-ide yang dimiliki dalam hal pemecahan masalah yang dibahas, dengan kegiatan ini maka siswa tidak hanya sekedar mengingat materi pelajaran yang dibahas, akan tetapi siswa mampu menguasai dan memahaminya secara penuh. Dalam fase ini juga siswa secara berkelompok ditugaskan untuk mempresentasikan hasil laporan diskusi kepada teman dan guru, sehingga dengan kegiatan ini siswa akan memperoleh kemampuan berkomunikasi dalam presentasi, menanggapi pendapat orang lain, bertanggung jawab dan berpikir logis yang merupakan cerminan dari sikap, hal ini terlihat dari hasil observasi sikap siswa selama kegiatan pembelajaran mengalami peningkatan tiap pertemuan. Melalui fase tersebut juga keterampilan siswa juga akan muncul, misalnya keterampilan dalam melakukan studi literatur, melakukan 
percobaan, menggunakan alat praktikum, mengumpulkan data serta membuat laporan hasil diskusi.

Penggunaan model pembelajaran berdasarkan masalah dapat meningkatkan hasil belajar siswa, namun tetap saja masih terdapat siswa dalam kriteria tidak tuntas dan selama pembelajaran masih terdapat kendala yang dihadapi peneliti yaitu siswa masih sulit mengkondisikan diri dalam kelompok sehingga banyak waktu yang tersita pada saat pembagian kelompok. Hal ini disebabkan karena siswa belum terbiasa dengan belajar berkelompok.

Kesulitan kedua adalah siswasiswa masih malu-malu dalam melakukan presentasi dan siswa masih takut-takut dalam mengeluarkan pendapat dan bertanya kepada kelompok yang sedang presentasi ataupun kepada guru. Untuk mengatasi kendala ini peneliti harus lebih memotivasi siswa agar tidak malu-malu dalam melakukan presentasi serta membantu kelompok yang mengalami kesulitan dalam melakukan presentasi dan memotivasi siswa untuk berani mengeluarkan pendapat dan bertanya dengan memberikan penghargaan berupa pujian kepada siswa yang berani mengeluarkan pendapat dan bertanya.

Kesulitan yang ketiga adalah siswa kurang memanfaatkan kelompoknya untuk berdiskusi dalam menyelesaikan tugas yang diberikan guru. Untuk mengatasi kendala tersebut peneliti memberikan pengarahan kepada setiap kelompok untuk saling berdiskusi, mengeluarkan pendapat, tukar pikiran serta menyatukan pikiran-pikiran atau ide setiap anggota kelompok untuk menyelesaikan tugas yang diberikan guru.
Tidak hanya pada penelitian ini, kesulitan juga terjadi pada penelitian sebelumnya yang dilakukan oleh Elviarni (2012), siswa kurang bekerjasama dengan guru dalam proses belajar mengajar, perbedaan karakter siswa membuat siswa sulit untuk dapat bergabung menjadi satu kelompok, sehingga diperlukan waktu untuk siswa dapat menyatukan suara dalam diskusi kelompok, meskipun mengalami kendala hasil penelitian menyatakan bahwa penerapan model pembelajaran berdasarkan masalah memberikan pengaruh baik terhadap hasil belajar.

Hasil yang sama juga diperoleh dari penelitian Mutoharoh (2012), penerapan model pembelajaran berdasarkan masalah dapat dijadikan sebagai alternatif dalam pembelajaran IPA khususnya fisika dan hasil penelitian yang dilakukan oleh Medriati (2013), model PBL dapat meningkatkan hasil belajar dan aktivitas siswa, siswa mampu mengorganisasikan tugas belajar yang berhubungan dengan permasalahan yang akan dipecahkan, melakukan percobaan untuk mendapatkan penjelasan dan pemecahan masalah dan percaya diri mempresentasikan hasil karyanya.

Beberapa penelitian tersebut sesuai yang diungkapkan oleh Arends (2013), "Pengajaran berdasarkan masalah merupakan suatu pendekatan pembelajaran dimana siswa mengerjakan permasalahan yang autentik dengan maksud untuk menyusun pengetahuan mereka sendiri, mengembangkan inkuiri dan keterampilan berpikir tingkat lebih tinggi, mengembangkan kemandirian dan percaya diri". 


\section{KESIMPULAN DAN SARAN \\ Kesimpulan}

Hasil analisis yang dilakukan dalam penelitian ini diperoleh kesimpulan yaitu hasil belajar siswa yang diajar dengan model pembelajaran berdasarkan masalah diperoleh rata-rata sebesar 81,08 dengan 86,48 \% siswa tuntas. Hasil belajar siswa yang diajar dengan model pembelajaran konvensional diperoleh rata-rata sebesar 77,13 dengan $71,97 \%$ siswa tuntas. Hasil uji hipotesis menunjukkan bahwa ada perbedaan akibat pengaruh model pembelajaran berdasarkan masalah terhadap hasil belajar siswa pada materi pokok suhu dan kalor kelas $\mathrm{X}$ semester II SMA Negeri 1 Langsa T.P 2014/2015.

\section{Saran}

Kepada peneliti selanjutnya agar memberikan pengarahan terlebih dahulu sebelum pembelajaran dimulai kepada setiap kelompok untuk saling berdiskusi, mengeluarkan pendapat, tukar pikiran serta menyatukan pikiran-pikiran atau ide setiap anggota kelompok untuk menyelesaikan tugas yang diberikan guru. Kepada peneliti selanjutnya agar lebih memotivasi siswa agar tidak malu-malu dalam melakukan presentasi dan memotivasi siswa untuk berani mengeluarkan pendapat dan bertanya dengan memberikan penghargaan berupa pujian kepada siswa yang berani mengeluarkan pendapat dan bertanya.

\section{DAFTAR PUSTAKA}

Arends, R. I., (2013), Learning to teach, Humanika Salemba,Yogyakarta.

Elviarni, (2010), Pengaruh Penggunaan Metode PBL
Secara Kooperatif Terhadap Hasil Belajar Fisika Siswa Di SMK-TR Raksana Medan, Skripsi Tidak diterbitkan.

Dimayati dan Mudjiono, (2011), Belajar dan Pembelajaran, PT Rineka Cipta, Jakarta.

Kunandar, (2010), Guru Profesional Implementasi KTSP dan Sukses dalam Sertifikasi Guru, PT Raga Grafindo Persada, Jakarta.

Medriati, R, (2013). Upaya Peningkatan Hasil Belajar Fisika Siswa Pada Konsep Cahaya Kelas VII6 Melalui Penerapan Model PBL Berbasis Laboratorium di SMPN 14 Kota Bengkulu, Skripsi tidak diterbitkan.

Mutoharoh, (2011), Pengaruh Model Pembelajaran Berbasis Masalah Terhadap Hasil Belajar Fisika Siswa, Skripsi tidak diterbitkan.

Rusman, (2012), Model-Model Pembelajaran, PT Raja Grafindo Persada, Jakarta.

Sanjaya, Wina, (2009), Strategi Pembelajaran Berorientasi Standar Proses Pendidikan, Kencana Prenada Media Group, Jakarta.

Trianto, (2012), Mendesain ModelModel Pembelajaran Inovatif Berorientasi Konstruktivistik, Prestasi Pustaka, Jakarta.

http://m.tribunnews.com/nasional/201 5/02/11perlu-solusi-barumeningkatkan-kualitaspendidikan-dan-sdm (diakses : 10 Maret 2015). 